\title{
ANALISIS KEBUTUHAN PEMBELAJARAN ILMU PENGETAHUAN SOSIAL DI SEKOLAH DASAR
}

\author{
Anang Yulianto Nugroho, Hartono, dan Sudiyanto \\ Program Pascasarjana Universitas Sebelas Maret \\ email: anang_gurusd@yahoo.co.id
}

\begin{abstract}
Abstrak
Tujuan dari penelitian ini adalah untuk mengeksplorasi hambatan dan kebutuhan dalam proses pembelajaran ilmu pengetahuan sosial (IPS) di sekolah dasar. Penelitian ini mengunakan pendekatan deskriptif. Pengumpulan data dilakukan dengan observasi proses pembelajaran IPS, analisis bahan ajar, dan mencermati rata-rata nilai tes peserta didik. Penelitian dilakukan selama lima bulan mulai dari April 2017 sampai dengan Agustus 2017. Data yang terkumpul di lakukan trianggulasi teknik untuk mengetahui keterkaitan dan kesepadanan data. Setelah itu data dianalisis menggunakan analisis miles interaktif menurut Miles Huberman. Hasil penelitiannya yaitu buku pelajaran yang digunakan kurang menarik karena banyak tulisan dan sedikit gambar yang memacu peserta didik untuk berpikir kritis; guru cenderung ceramah dan tanya jawab dalam proses pembelajaran; peserta didik dalam belajar cenderung menghafalkan daripada menguasai materi pelajaran; keterbatasan penggunaan media pembelajaran oleh guru materi pembelajaran menjadi abstrak bagi peserta didik padahal pembelajaran peserta didik sekolah dasar harus memperhatikan perkembangan cara berpikir peserta didik dari konkret ke abstrak. Inovasi pembelajaran yang sesuai dengan karakteristik peserta didik sekolah dasar akan mampu menciptakan pembelajaran yang bermakna.
\end{abstract}

Kata kunci: analisis kebutuhan, ilmu pengetahuan sosial, sekolah dasar

\section{NEEDS ANALYSIS IN SOCIAL SCIENCE LEARNING AT PRIMARY SCHOOL}

\begin{abstract}
This study was aimed at exploring the obstacles and the needs in teaching social science at the primary school level. A descriptive approach method was used in this study. The data was obtained by observing the learning process, analyzing the teaching materials and media in learning, and analyzing the students' test scores. The study was conducted for 5 months starting from April 2017 to August 2017. The collected data were examined by triangulation techniques to determine the relationship and comparability of the data. Data were then analyzed using the interactive-miles analysis according to Miles Huberman. The results show that the hand books were not interesting enough as there were too many theories but few pictures which would not encourage students to think critically; teachers tended to adopt a teacher-centered approach of teaching in which they dominated the class with their explanation and there were limited interactive sessions; the students tended to memorize more than master the theories; having limited teaching medias, the teachers made the learning process become abstract, while primary-school students needed to have activities which encouraged their way of thinking from concrete into abstract. An innovation which suits primary school students' character is needed to create a meaningful learning process.
\end{abstract} Keywords: needs analysis, social science learning, primary school 


\section{PENDAHULUAN}

Pendidikan sebagai salah satu instrumen utama dalam pengembangan sumber daya manusia. Penyelenggaraan pendidikan menghendaki perencanaan dan pelaksanaan yang matang agar hasil yang diharapkan tercapai secara maksimal. Hal ini senada dengan UU SPN Nomor 20 Tahun 2003 Pasal 1yang menyebutkan bahwa pendidikan adalah usaha sadar dan terencana untuk mewujudkan suasana belajar dan proses pembelajaran agar peserta didik secara aktif mengembangkan potensi dirinya untuk memiliki kekuatan spiritual, keagamaan, pengendalian diri, kepribadian, kecerdasan, akhlak mulia, serta keterampilan yang diperlukan dirinya, masyarakat, bangsa dan negara. Sesuai dengan pendapat Sadiman, Rahardjo, Haryono, dan Harjito (2011, p. 9) bahwa proses pembelajaran harus dirancang secara sistematis dengan memusatkan perhatian pada peserta didik. Pembelajaran direncanakan berdasarkan kebutuhan dan karakteristik peserta didik serta diarahkan kepada perubahan tingkah laku peserta didik sesuai dengan tujuan yang akan tercapai.

Dalam mencapai tujuan pembelajaran diperlukan lingkungan pembelajaran yang kondusif. Lingkungan belajar diatur oleh guru mencakup tujuan pengajaran, bahan pengajaran, metodologi pengajaran dan penilaian pengajaran. Bahan ajar adalah seperangkat materi keilmuan yang terdiri atas fakta, konsep, prinsip, generalisasi suatu pengetahuan yang bersumber dari kurikulum dan dapat menunjang tercapainya tujuan pengajaran. Metodologi pengajaran adalah metode dan teknik yang digunakan guru dalam melakukan interaksinya dengan peserta didik agar bahan pengajaran sampai pada peserta didik, sehingga peserta didik mengetahui tujuan pengajaran (Sudjana \& Rivai, 2010, p. 1).
Ketercapaian tujuan pembelajaran dapat dilihat dari proses pembelajaran dan hasil pembelajaran ditunjukkan dengan adanya perubahan tingkah laku yang lebih baik dimana menyangkut perubahan pengetahuan (kognitif), keterampilan (psikomotor), maupun yang menyangkut nilai dan sikap (afektif). Ketercapaian perubahan-perubahan tersebut dipengaruhi oleh beberapa faktor antara lain, pendidik, peserta didik, lingkungan, serta perangkat pembelajaran yang mencakup media pembelajaran dan perangkat lainnya. Hal ini sejalan dengan Suhana (2014, p. 3) menjelaskan bahwa guru sebagai pelaku reformasi harus terus mensiasati membangun kultur belajar peserta didik, antara lain learning to know, learning to do, learning to be, dan learning to live together.

Dalam kenyataannya berdasarkan observasi yang dilakukan lingkungan pembelajaran dalam Mata Pelajaran Ilmu Pengetahuan Sosial (IPS) kurang mampu mendukung tercapainya tujuan dari ketiga aspek yang telah ditetapkan terutama dalam pembelajaran IPS. Permasalahan tersebut terletak pada metode pembelajaran, bahan ajar yang digunakan dan pemanfaatan media pembelajaran. Pemilihan salah satu metode mengajar tertentu akan mempengaruhi jenis media pengajaran yang sesuai, meskipun masih ada berbagai aspek lain yang harus diperhatikan dalam memilih media, antara lain tujuan pengajaran, jenis tugas dan respons yang diharapkan dapat dikuasai peserta didik setelah pengajaran berlangsung. Meskipun demikian, dapat dikatakan bahwa salah satu fungsi utama media pengajaran adalah sebagai alat bantu mengajar yang turut mempengaruhi iklim, kondisi, dan lingkungan yang diciptakan oleh guru.

Berdasarkan observasi yang dilakukan diketahui bahwa sarana dan prasarana 
di SDN Jurangjero 4 sangat mendukung untuk dapat mengembangkan media pembelajaran interaktif, inovatif dan dapat menarik minat belajar peserta didik. Dapat dilihat adanya sarana penunjang seperti LCD, komputer, dan guru yang dapat mengoperasikan alat tersebut. Akan tetapi, dari keadaan tersebut pembelajaran IPS masih bersifat monoton dan banyak peserta didik tidak memperhatikan karena materi sulit dihafal dan bersifat abstrak untuk dipahami. Guru di dalam kelas menerangkan materi berpatokan pada buku paket dan sesekali menggunakan media gambar, hal tersebut pembelajaran kurang bisa diterima oleh peserta didik dan menjadikan Mata Pelajaran IPS kurang diminati peserta didik dalam belajar serta mengganggap bahwa IPS itu pelajaran yang susah dimengerti. Misalnya pokok bahasan peninggalan sejarah dari masa HinduBuddha dan Islam di Indonesia merupakan cara yang vital dalam mengenalkan sejarah dan menumbuhkan rasa untuk menjaga dan melestarikan peninggalan sejarah yang dimiliki oleh Negara Indonesia.

Media pendidikan sesuai dengan kebutuhan dan kondisi materi pelajaran dapat membantu menciptakan lingkungan belajar yang kondusif dan menarik bagi peserta didik. Suyono dan Nurohman (2014) tujuan media pembelajaran adalah untuk memfasilitasi terjadinya proses komunikasi dan untuk meningkatkan hasil pembelajaran. Salah satu media yang mendukung dengan pembelajaran IPS adalah multimedia pembelajaran interaktif. Multimedia pembelajaran interaktif ini bisa di gunakan pada pembelajaran di SDN Jurangjero 4 karena terdapat sarana dan prasarana yang memadai seperti Proyektor LCD, komputer atau laptop serta kemudahan bagi guru dan peserta didik dalam mengoperasikan media pembelajaran interaktif ini.
Multimedia pembelajaran interaktif merupakan suatu media yang dapat digunakan guru dalam mengajar yang memiliki kelengkapan media seperti suara, teks, gambar, animasi, dan video yang dapat menambah serta merangsang peserta didik dalam belajar. Kegunaan Multimedia Pembelajaran Interaktif(MPI) dalam proses pembelajaran yaitu mengatasi keterbatasan ruang dan waktu, memperjelas penyajian pesan, mencegah timbulnya verbalisme, mengatasi sikap pasif peserta didik, menjadikan lebih interaktif, kreatif dan aktif secara mandiri, mentransmisikan pesanpesan pembelajaran lebih konstruktif dan menarik. Diharapkan dengan memanfaatkan multimedia pembelajaran interaktif peserta didik dapat menguasai materi dengan baik dan dapat memiliki motivasi lebih dalam belajar sehingga hasil belajar dapat meningkat.

Dalam pembelajaran IPS di sekolah dasar harus memperhatikan cara berpikir peserta didik dari konkret ke abstrak. Anak sekolah dasar berusia antara 6-12 tahun memiliki karakter bahwa kehidupan sosialnya diperkuat, selain kemampuan dalam hal kerjasama juga dalam hal bersaing dan kehidupan kelompok sebaya, semakin menyadari diri selain mempunyai keinginan, perasaan tertentu juga semakin bertumbuhnya minat tertentu, kemampuan berfikirnya masih dalam tingkatan persepsional serta ketergantungan kepada orang dewasa semakin berkurang dan kurang memerlukan perlindungan orang dewasa.

Proses pembelajaran dan media pembelajaran memiliki kaitan yang sangat erat, proses pembelajaran tidak akan berjalan lancar tanpa adanya media pembelajaran yang tepat. Media adalah perantara atau pengantar pesan dari pemberi kepada penerima pesan. Association for Education Communicational and Technology (AECT) menjelaskan bahwa media adalah segala 
bentuk dan saluran yang digunakan orang untuk menyalurkan pesan atau informasi (1977). Penggunaan media yang tepat mampu menyampaikan informasi maupun pesan yang disampaikan oleh penyampai pesan dapat diterima dengan jelas oleh penerima pesan. Begitu juga ketika media digunakan dalam proses pembelajaran di kelas, informasi yang disampaikan guru sebagai penyampai pesan di kelas dapat diterima dengan jelas oleh peserta didik sebagai penerima pesan di kelas.

Pemanfaatan media yang baik serta memadai, diharapkan dapat merangsang pikiran, perasaan, perhatian dan minat peserta didik sehingga proses pembelajaran dapat berjalan dengan baik dan menggairahkan. Verbalisme mungkin saja akan muncul ketika pembelajaran tanpa menggunakan media. Namun, dengan menggunakan media unsur verbalisme dapat dikurangi bahkan dihilangkan. Mengurangi atau menghilangkan unsur verbalisme, maka peserta didik akan diberikan pengertian dan konsep yang sebenarnya secara realistis dan teliti, serta memberi pengalaman menyeluruh yang pada akhirnya memberi pengertian yang konkret. Hal ini sejalan dengan penelitian Garcia, Quirós, Santos, González, \& Fernanz (2007) menyatakan bahwa berkembanganya kekhawatiran guru untuk meningkatkan kelas teoritis mereka bersama-sama dengan revolusi dalam isi dan metode yang dibawa oleh informasi teknologi baru bergabung untuk menawarkan peserta didik bentuk yang lebih menarik, efisien, dan menyenangkan untuk belajar. Model kognitif dalam Interactive Multimedia Authoring (IMA) mempengaruhi kognisi peserta didik dalam pemrograman berorientasi obyek (Yuen \& Liu, 2013). Penelitian di atas sebagai salah satu manfaat penggunaan media yang berorientasi pada cara berpikir konkret ke abstrak.
Penelitian ini relevan dengan penelitian Poole dan Kenna (2013); Cummings (2014). Penelitian ini berbeda dengan penelitian sebelumnya terletak pada subjek yang diteliti dan aspek penelitian yang berfokus pada hambatan pembelajaran IPS.

Pembelajaran $11 \mathrm{mu}$ pengetahuan sosial di sekolah dasar perlu dioptimalkan sebagai suatu ilmu yang mengkaji tentang masyarakat yaitu mengenai hubungan manusia dengan lingkungan sosialnya. Hal ini dikarenakan pembelajaran IPS menjadi program pendidikan yang mengintegrasikan konsep-konsep terpilih dari ilmu-ilmu sosial dan humaniora untuk tujuan pembinaan warga negara yang baik. Mata Pelajaran IPS mempunyai peran penting bagi peserta didik dapat memperoleh pengetahuan dan wawasan tentang konsep-konsep dasar ilmu-ilmu sosial, memiliki kepekaan dan kesadaran terhadap masalah sosial di lingkungannya, serta memiliki keterampilan mengkaji dan memecahkan masalah-masalah sosial.

Terkait dengan fenomena dan permasalahan pembelajaran IPS di sekolah dasar di atas maka dalam penelitian ini dapat dirumuskan bagaimana kebutuhan media pembelajaran interaktif IPS di sekolah dasar.

\section{METODE}

Penelitian ini dilaksanakan di SDN Jurangjero 4 di Kabupaten Sragen. Penelitian dilakukan selama 5 bulan mulai dari April 2017 sampai dengan Agustus 2017. Kegiatan penelitian mencakup persiapan penelitian, pengumpulan dan pengolahan data, serta penyusunan laporan penelitian. Penelitian ini menggunakan pendekatan deskriptif kualitatif. Jenis penelitian yang digunakan dalam penelitian ini adalah deskriptif.

Penelitian deskriptif bermaksud memberikan gambaran suatu gejala tertentu, 
sudah ada informasi mengenai gejala-gejala yang akan diteliti seperti yang dimaksudkan dalam suatu permasalahan penelitian namun belum memadai. Penelitian deskriptif menjawab pertanyaan apa dengan penjelasan yang lebih terperinci dalam suatu permasalahan penelitian yang bersangkutan. Teknik pengumpulan data dalam penelitian ini menggunakan teknik observasi partisipatoris dan wawancara mendalam dengan menggunakan instrumen sebagi pedoman observasi dan wawancara. Dalam penggumpulan data peneliti menggunakan instrumen yang telah divalidasikan. Data yang terkumpul di lakukan trianggulasi teknik untuk mengetahui keterkaitan dan kesepadanan data. Setelah itu data dianalisis menggunakan analisis miles interaktif menurut Miles Huberman.

\section{HASIL PENELITIAN DAN PEMBAHASAN}

Penelitian ini difokuskan pada pendes-kripsian mengenai kebutuhan baik oleh guru maupun peserta didik dalam melaksanakan pembelajaran IPS. Salah satu titik tolak dalam analisis kebutuhan terletak pada penggunaan media interaktif dalam pembelajaran IPS di sekolah dasar. Dari hasil observasi di kelas V pada tanggal 23 April 2017 di SDN Jurangjero 4 ditemukan bahwa masih banyak permasalahan dalam hal kebutuhan media di pembelajaran IPS yang dapat dilihat pada pemaparan berikut ini.

Persiapan Pembelajaran. Berdasarkan observasi kegiatan pembelajaran menunjukkan bahwa guru telah mempersiapkan rencana pelaksanaan pembelajaranIPS sebelum kegiatan belajar mengajar berlangsung. Dalam hal ini menunjukkan persiapan kegiatan belajar mengajar mulai dari kegiatan awal, inti, dan kegiatan akhir pembelajaran sudah sesuai dengan peraturan yang ada yang dikembangkan dalam pembelajaran. Akan tetapi, dalam kegiatan inti pembelajaran belum semuanya menggunakan media pembelajaran yang sesuai. Dengan kondisi tersebut berimbas pada proses dan hasil pembelajaran yang kurang maksimal.

Proses Pembelajaran. Diketahui bahwa guru menyampaikan materi pelajaran di dalam kelas mengalami banyak kesulitan. Kurangnya fasilitas pendukung dalam pembelajaran menyebabkan materi selalu terlihat abstrak dan sulit dipahami. Sebagai sampel guru dan peserta didik melakukan pembelajaran mengenai peninggalanan sejarah kerajaan hindu dan budha di Indonesia. Guru hanya menggunakan ceramah dan peserta didik mendengarkan serta sesekali guru melakukan tanya jawab kepada peserta didik. Peserta didik yang duduk di depan dan di belakang tidak memperhatikan guru, bercerita dengan temannya sendiri bahkan banyak yang mengantuk.

Salah satu materi IPS yang perlu adanya media interaktif adalah materi peninggalan sejarah kerajaan hindu dan budha, karena kurang efektif jika guru menjelaskan kepada peserta didik hanya menggunakan metode ceramah dan tanya jawab saja. Peserta didik hanya membayangkan bentuk-bentuk peninggalan sejarahnya tanpa melihat secara konkret dengan bantuan media pembelajaran dan alat peraga yang sesuai.

Temuan selanjutnya guru dalam menyampaikan materi pelajaran di dalam kelas mengalami kesulitan. Dapat diambil satu kegiatan pembelajaran pada materi keutuhan Negara Kesatuan Republik Indonesia. Dalam materi tersebut jika tidak didukung dengan media yang konkret dalam pembelajaran menyebabkan materi selalu terlihat abstrak dan sulit dipahami oleh peserta didik. Guru di dalam kelas menerangkan materi berpatokan pada buku paket dan sesekali menggunakan media 
gambar. Peserta didik yang memperhatikan terlihat kurang paham. Dalam pokok bahasan peninggalan sejarah dari masa Hindu-Budha dan Islam di Indonesia terlihat peserta didik kurang memperhatikan dan banyak peserta didik yang mengantuk dan ramai sendiri disebabkan karena guru didominasi metode ceramah.

Dalam kegiatan proses belajar mengajar ditemui bahwa peserta didik bersifat pasif dan hanya mendengarkan penjelasan dari guru. Pembelajaran yang dilakukan juga berbasis klasikal tanpa melibatkan peserta didik dalam kerja sama atau diskusi. Selain itu guru mengalami kesulitan pada saat menyampaikan materi yang bukan merupakan bidang ilmunya. Guru dituntut untuk dapat menyampaikan materi IPS dengan waktu yang terbatas. Selain itu, penggunaan metode pembelajaran IPS yang bervariasi belum dapat diaplikasikan. Selain faktor dari guru terdapat faktor dari peserta didik yaitu tidak semua peserta didik siap untuk mengikuti pembelajaran dan peserta didik kurang mempunyai antusias pada Mata Pelajaran IPS.

Evaluasi pembelajaran. Dalam penelitian ini ditemukan bahwa guru melakukan evaluasi pembelajaran dengan tidak menggunakan pedoman dan kriteria yang runtut dan sistematis. Sehingga ketercapaian peserta didik tidak terukur dengan baik dan tepat sasaran.
Buku pelajaran yang digunakan. Dalam buku mata pelajaran ilmu pengetahuan sosial yang berbasis kurikulum tingkat satuan pendidikan terlihat banyak tulisan, sedikit ilustrasi dan kurang menarik perhatian peserta didik.

Pada hasil wawancara secara mendalam diketahui bahwa guru kurang mampu menggunakan fasilitas pendukung berbasis IT untuk materi pelajaran yang bersifat abstrak. Hal itu dikarenakan guru mengejar ketercapaian setiap kompetensi dasar dengan keterbatasan waktu yang ada. Guru terkadang tidak menguasai materi pelajaran yang ingin disampaikan. Selanjutnya dalam materi IPS yang cenderung hafalan menyebabkan peserta didik mudah mengantuk dan kurang memperhatikan materi yang disampaikan. Dengan keterbatasan penggunaan media pembelajaran yang mampu mencakup materi, ruang dan waktu mengakibatkan rendahnya pencapaian kemampuan peserta didik dapat dilihat pada Gambar 1.

Terkait dengan deskripsi di atas bertolak belakang dengan tujuan dari proses pendidikan di sekolah dasar yaitu supaya peserta didik mampu memahami potensi diri, memiliki peluang, dan memahami tuntutan lingkungan serta dapat merencanakan masa depan mengenai serangkaian keputusan yang paling mungkin bagi dirinya. Tujuan akhir pendidikan dasar adalah diperolehnya

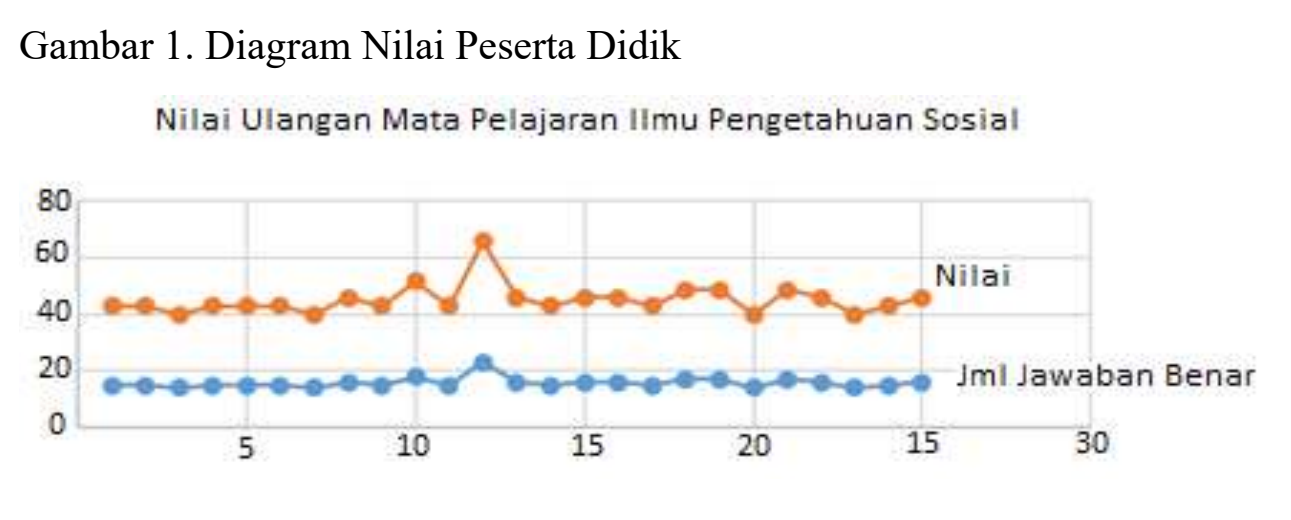


pengembangan pribadi anak yang dapat membangun dirinya sendiri dan ikut serta bertanggungjawab terhadap pembangunan bangsa, mampu melanjutkan ke tingkat pendidikan yang lebih tinggi, dan mampu hidup di masyarakat dan mengembangkan diri sesuai dengan bakat, minat, kemampuan, dan lingkungan.

Media pembelajaran seharusnya dijadikan alat yang pokok dalam menyampaikan informasi pada penerima pesan bahwa pesan dapat tersampaikan, dalam dunia pendidikan media dapat membantu guru saat proses pembelajaran berlangsung guna memudahkan pemaham-an peserta didik. Didukung juga dengan pendapat Susanto (2013, p. 4) bahwa belajar adalah suatu aktivitas yang dilakukan seseorang dengan sengaja dalam keadaan sadar untuk memperoleh suatu konsep, pemahaman atau pengetahuan baru sehingga memungkinkan seseorang terjadinya perubahan perilaku yang relatif tetap baik dalam berpikir, merasa, maupun dalam bertindak. Pengembangan Kurikulum 2013 pada hakekatnya didasarkan pada tantangan masa depan, seperti adanya globalisasi, permasalahan lingkungan hidup, kemajuan ilmu pengetahuan dan teknologi (Suyantiningsih, Munawaroh, \& Rahmadona, 2016).

Hasil penelitian ini relevan dengan penelitian Sumantri, Bayu, dan Sugiarta (2017) yang menemukan bahwa hambatan dalam pembelajaran IPS adalah terbatasnya kemampuan dan keterampilan instruksional guru itu sendiri, terbatasnya sarana dan prasarana pembelajaran yang dapat dijadikan sebagai media pembelajaran IPS yang multikultur, jumlah kelas yang relatif banyak melebihi batas normalnya dengan peserta didik di atas 45 orang sangat menyulitkan guru dalam melakukan layanan belajar dan mengelola kelas, dan model-model pembelajaran pendidikan multikultur yang ada di sekolah sangat terbatas.

Materi pembelajaran IPS di SD yang syarat dengan konsep, pengertian, dan prinsip-prinsip abstrak, perlu mendapatkan perhatian yang serius agar tujuan pembelajaran lebih bermakna. Kebermaknaan tujuan pembelajaran ini, akan lebih baik dan efektif manakala bahan ajar dan tugas-tugas yang diberikan dirasakan akrab, intim, dan menyentuh diri peserta didik. Ausebel (Thobroni \& Mustofa, 2011, p. 82) menegaskan bahwa kebermaknaan belajar dapat diraih manakala terjadi hubungan substantive aspek konsepkonsep, informasi atau situasi baru dengan komponen yang relevan terdapat dalam struktur dalam diri peserta didik. Baik dalam hubungan-hubungan yang bersifat derivatif, korektif, suportif maupun yang bersifat hubungan-hubungan kualitatif.

Tujuan pendidikan IPS dalam Permen Nomor 22 Tahun 2006 tentang Standar Isi dirumuskan secara jelas bahwa tujuan Mata Pelajaran IPS pada tingkat satuan pendidikan SD/MI adalah mengenal konsepkonsep yang berkaitan dengan kehidupan masyarakat dan lingkungannya, memiliki kemampuan dasar untuk berpikir logis dan kritis, rasa ingin tahu, inquiri, memecahkan masalah dan keterampilan dalam kehidupan sosial, memiliki komitmen dan kesadaran terhadap nilai-nilai sosial dan kemanusiaan, memiliki kemampuan berkomunikasi, bekerja sama dan berkompetisi dalam masyarakat yang majemuk, tingkat lokal, nasional dan global.

Hasil penelitian relevan selanjutnya yaitu pengembangan pembelajaran IPS di sekolah dasar berdasarkan preskripsi component display theory (CDT) oleh Hidayanto (1999) yang menemukan gambaran dalam pelaksanaan pembelajaran IPS adalah kesulitan guru untuk menghasilkan metode atau model pembelajaran dan 
media pembelajaran IPS yang efektif dan tepat sasaran. Hal itu dikarenakan materi pembelajaran IPS yang memiliki cakupan materi yang cukup kompleks dan bersifat abstrak jika hanya dipahami melalui membaca saja.

Penelitian ini juga ada keterkaitan dengan penelitian sebelumnya yaitu penggunaan metode Jigsaw dengan bantuan media untuk meningkatkan keterampilan kerja sama dan hasil belajar IPS (Rochaniningsih \& Masruri, 2015). Hasil penelitian Jamrut dan Aman (2014) menemukan bahwa hasil belajar IPS meningkat melalui implementasi CTL metode GI berbantuan media.

Dari hasil penelitian di atas ditemukan kendala pembelajaran IPS sebelum dilakukan eksperimen yaitu guru belum optimal menumbuhkan sikap kritis, aktif, dan santun. Proses belajar mengajar lebih banyak berpusat pada guru, murid hanya mencatat materi pelajaran. Peserta didik kurang semangat dalam mengikuti kegiatan pembelajaran. Pembelajaran IPS tidak memanfaatkan lingkungan alam sekitar sebagai media. Kondisi ini tidak mampu dibaca oleh guru sehingga mengakibatkan pelajaran IPS menjadi sesuatu yang tidak berarti. Guru yang sesuai tantangan abad 21 adalah guru yang mampu membaca situasi dan kondisi, memanfaatkan semua sumber belajar, menggunakan media pembelajaran, menggunakan model, metode, teknik maupun pendekatan pembelajaran yang kreatif, inovatif, bermakna, dan menyenangkan.

Solusi dengan keadaan materi pembelajaran yang sebagian besar bersifat abstrak perlu didukung dengan media atau alat peraga yang sesuai. Multimedia pembelajaran interaktif merupakan suatu media yang dapat digunakan guru dalam mengajar yang memiliki kelengkapan media seperti suara, teks, gambar, animasi, video yang dapat menambah serta merang-sang peserta didik dalam belajar. Kegunaan Multimedia
Pembelajaran Interaktif(MPI) dalam proses pembelajaran mampu yang dapat digunakan sebagai media pembelajaran. Namun program yang lebih baik digunakan yaitu program yang menyajikan multimedia yang interaktif. Unsur interaktif ini yang dapat mengajak peserta didik aktif dalam belajar. Salah satu program yang dapat digunakan yaitu Adobe Flash. Keistimewaan program ini yaitu menyajikan berbagai macam media yaitu suara, teks, animasi, gambar, serta video yang lebih luwes, bisa di desain sesuai dengan kebutuhan yang ada di sekolah.

Pentingnya penggunaan media yaitu sebagai alat bantu dalam proses pembelajaran dan mengatasi keterbatasan kemampuan guru. Disadari oleh semua guru bahwa media pembelajaran sangat dibutuhkan dalam pembelajaran IPS, karena salah satu karakteristik IPS adalah peristiwa masa lampau dan bersifat abstrak, karena itu agar gambaran setiap peristiwa secara jelas dapat diterima peserta didik, dibutuhkan keterampilan guru dalam mengembangkan dan menggunakan media pembelajaran. Salah satunya pembelajaran dengan bantuan multimedia interaktif. Dengan mengubah materi yang masih bersifat abstrak menjadi lebih konkret maka peserta didik dapat memahami informasi yang berhubungan dengan beberapa pertanyaan what, when, who, where, why, dan how. Melalui media pembelajaran interaktif maka pembelajaran tidak membosankan, peserta didik mampu menyerap nilai-nilai yang dapat diteladani dapatmengaplikasikan nilai dalam kehidupan sehari-hari. Pemahaman guru yang demikan ini mempunyai pengertian bahwa guru IPS dituntut mengaplikasikan berbagai model pembelajaran dan mengembangkan media pembelajaran yang tepat.

Penggunaan media pembelajaran melalui pembelajaran IPS memang perlu persiapan pembelajaran yang didukung pula oleh sarana prasarana yang memadai, 
serta dapat menciptakan lingkungan sebagai sumber belajar agar nilai-nilai karakter yang dikembangkan dalam pembelajaran IPS dapat benar-benar nyata (kontektual) sesuai dengan kehidupan sehari-hari. Dengan pembelajaran IPS perlu disesuaikan dengan kehidupan sehari hari karena dalam pembelajaran IPS terkandung pendidikan karakter yang harus diaktualisasikan.

Pembelajaran IPS memiliki relevansi yang penting berkaitan dengan pembentukan karakter bangsa. Pembelajaran IPS diharapkan dapat mengantarkan peserta didik menjadi warga negara yang kritis dan demokratis, menjunjung tinggi kemerdekaan dan mencintai tanah air, toleransi dan menghargai orang lain, memiliki kearifan, dan kecerdasan sosial (Sadono \& Masruri, 2014).

Salah satu faktor penyebab minimnya pengunakan media pembelajaran seperti media pembelajaran interaktif adalah tidak tersedianya media itu di lapangan. Kalaupun membuat, para guru tidak menguasai teknik pembuatan media yang dimaksud. Sementara itu, pengadaan media pembelajaran yang mendekatkan peserta didik dengan subjek dalam materi pengetahuan sosial sangat diperlukan. Media pembelajaran yang baik, diharapkan dapat mencakup aspek pengelihatan (visual), pendengaran (audio), dan gerak (motorik). Hal ini bertujuan untuk memudahkan para para peserta didik dalam memahami materi dan agar para peserta didik mampu menanamkan konsep yang yang terkandung dalam materi pelajaran. Semakin banyak indera peserta didik yang terlibat dalam proses belajar, maka akan semakin mudah peserta didik belajar dan semakin bermakna.

Setiap peserta didik memiliki perbedaan dalam aspek intelektual, psikologis, dan biologis. Ketiga aspek tersebut melahirkan variasi sikap dan tingkah laku peserta didik disekolah. Hal itu pula yang menjadikan pekerjaan guru dalam mengelola kelas dengan baik dan menentukan media pembelajaran yang sesuai. Selain pemilihan pendekatan pembelajaran yang tepat, juga perlu memanfaatkan beberapa media pendidikan yang telah ada dan mengupayakan pengadaan media pendidikan baru. Guna meningkatkan pemahaman peserta didik terhadap sisi dalam peristiwa dalam pengetahuan sosial, guru dapat melakukan variasi dalam proses belajar mengajar, salah satunya melalui penggunaan media pembelajaran interaktif. Pengembangan multimedia interaktif dengan pendekatan saintifik layak dan efektif untuk pembelajaran (Candra \& Masruri, 2015). Keberhasilan multimedia interaktif juga berpengaruh terhadap hasil belajar dan karakter peserta didik (Suyantiningsih, Munawaroh, \& Rahmadona (2016).

Guru mempunyai peran penting terhadap keberhasilan siswa, khususnya di sekolah dasar. Siswa akan belajar apapun yang diajarkan oleh guru. Jika guru tidak mengembangkan kemampuan siswa secara holistik dan tidak memberikan keterampilan tingkat tinggi kepada siswa, siswa pun tidak akan mempelajari keterampilan tersebut (Pujiastuti, Kawuryan, \& Ambarwati, 2017). Oleh karena itu, guru harus mampu mengembangkan kemmapuan peserta didik dalam ranah kognitif afektif dan psikomotor dengan memperhatikan prinsip pemilihan materi ajar, model atau metode pembelajaran dan media pembelajaran yang digunakan. Prinsip-prinsip dalam pemilihan materi pembelajaran dan media pembelajaran yang efektif dan efisien meliputi prinsip relevansi, konsistensi dan kecukupan. Prinsip relevansi artinya materi pembelajaran hendaknya relevan memilki keterkaitan dengan pencapaian standar kompetensi dan kompetensi dasar. Prinsip konsistensi artinya adanya keajegan antara 
media pembelajaran dengan kompetensi dasar yang harus dikuasai peserta didik. Prinsip kecukupan artinya materi yang diajarkan melalui media tersebut hendaknya cukup memadai dan membantu peserta didik menguasai kompetensi dasar yang diajarkan.

\section{SIMPULAN}

Dalam pembelajaran IPS masih memiliki beberapa hambatan dan kebutuhan. Pertama, dari sisi buku pelajaran yang digunakan kurang menarik karena banyak tulisan dan sedikit gambar yang memacu peserta didik untuk berpikir kritis. Kedua, guru cenderung ceramah dan tanya jawab dalam proses pembelajaran. Ketiga, peserta didik dalam belajar cenderung menghafalkan materi pelajaran dan mengantuk saat proses pembelajaran. Keempat, peserta didik kurang antusias dalam belajar IPS. Kelima, dengan keterbatasan penggunaan media pembelajaran oleh guru materi pembelajaran menjadi abstrak bagi peserta didik padahal pembelajaran peserta didik sekolah dasar harus memperhatikan perkembangan cara berpikir peserta didik dari konkret ke abstrak. Hambatan tersebut harus segera di selesaikan dengan perbaikan proses pembelajaran yang memanfaatkan alat peraga atau media pembelajaran seperti multimedia dan buku ajar yang digunakan. Dengan adanya inovasi pembelajaran yang sesuai dengan karakteristik peserta didik sekolah dasar mampu menciptakan pembelajaran yang bermakna. Salah satu inovasi yang dapat digunakan adalah penggunaan media yang berbasis multimedia interaktif. Hal ini dikarenakan karakteristik pembelajaran IPS yang kompleks terkait sejarah dan peristiwa kehidupan yang abstrak jika dibelajarkan tanpa bantuan media yang mampu membawa materi abstrak menjadi lebih konkret pada peserta didik.

\section{DAFTAR PUSTAKA}

AECT. (1977). Selecting media for learning. Washington DC: Association for Education Communicational and Technology.

Sadiman, A. S., Rahardjo, Haryono, A., \& Harjito. (2011). Media pendidikan: Pengertian, pengembangan, dan pemanfaatannya. Jakarta: PT Grafindo Persada.

Candra, A. A., \& Masruri, M. S. (2015). Pengembangan multimedia interaktif dengan pendekatan saintifik untuk pembelajaran PKn SMP. Harmoni Sosial: Jurnal Pendidikan IPS. 2 (2). 109-114.

Cummings, C. (2014). Intervention: An intervention system for traditional, blended, and online courses. The International Society For The Social Studies Annual Conference Proceedings, 2013(1), 37-40.

Hartoyo. (2009). Penerapan model pembelajaran kontekstual berbasis kompetensi untuk meningkatkan efektivitas pembelajaran. Jurnal Kependidikan. 1(1). 91-108.

Hidayanto, N. D. (1999). Pengembangan pembelajaran IPS SD berdasarkan preskripsi Component Display Theory (CDT). Jurnal Ilmu Pendidikan, 6(2), 140-149.

Jamrut, Aman. (2014). Peningkatan hasil belajar IPS melalui implementasi CTL metode GI berbantuan media SMP Negeri 6 Raha. Jurnal Kependidikan, 1(2). 142-154.

Poole, C. M., \& Kenna, J. L. (2013). Teaching students about contemporary germany. The International Society For The Social Studies Annual Conference Proceedings, 2013(1), 9-11.

Pujiastuti, P. Kawuryan, S., P., \& Ambarwati, U. (2017). Evaluasi pembelajaran 
tematik di sekolah dasar. Jurnal Kependidikan, 1(2), 187-199.

Rochaniningsih, N. S., \& Masruri, M. S. (2015). Penggunaan metode jigsaw dengan bantuan media untuk meningkatkan keterampilan kerja sama dan hasil belajar IPS. Harmoni Sosial: Jurnal Pendidikan IPS, 2(1), 42-54.

García, R. R., Quirós, J. S., Santos, R. G., González, S.M.,\&Fernanz, S.M.(2007). Interactive multimedia animation with macromedia flash in descriptive geometry teaching. Computers \& Education, 49(3), 615-639.

Sadono, M. Y., \& Masruri, M. S. (2014). Keefektifan VCT dalam pembelajaran sejarah untuk meningkatkan nilai nasionalisme, demokrasi, dan multikultural. Harmoni Sosial: Jurnal Pendidikan IPS, 1(1), 71-82.

Sudjana, N., \& Rivai, A. (2010). Media pengajaran. Bandung: Sinar Baru Algesindo.

Suhana, C. (2014). Konsep strategi pembelajaran. Bandung: PT Refika Aditama.

Sumantri, I. M., Bayu, G. W., \& Sugiartha, I. M. (2017). Analisis kebutuhan dalam pengembangan model pendidikan multikultur transformatif dalam pembelajaran PPKn dan IPS di Sekolah Dasar. Journal of Education Research and Evaluation, 1(3), 192-197.

Susanto, A. (2013). Teori belajar dan pembelajaran di sekolah dasar. Jakarta: Prenadamedia Group.

Suyantiningsih, Munawaroh, I., Rahmadona, S., (2016). Pengembangan multimedia pembelajaran berbasis scientific approach terintegrasi nilai karakter. Jurnal Kependidikan, 46(1). 1-13.

Suyono, \& Nurohman, S. (2014). Pengembangan modul elektronik berbasis web sebagai media pembelajaran fisika. Jurnal Kependidikan, 44(1), 73-82.

Thobroni, M., \& Mustofa,A. (2011). Belajar dan pembelajaran: Pengembangan wacana dan praktik pembelajaran dalam pembangunan nasional. Yogjakarta: Ar-Ruzz Media.

Pemerintah Republik Indonesia. (2003). Undang-Undang Republik Indonesia Nomor 20 tahun 2003 tentang Sistem Pendidikan Nasional.

Yuen, T., \& Liu, M. (2011). A cognitive model of how interactive multimedia authoring facilities conceptual understanding of object-oriented programming in novices. Journal of Interactive Learning, 22(3), 329-356. 